\title{
Down to Earth Benefits of People-Plant Interactions in Our Community
}

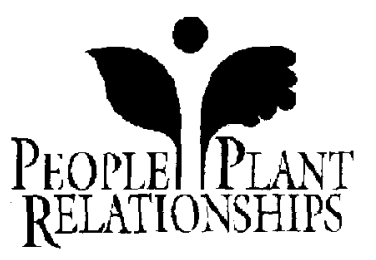

James W. Zampini

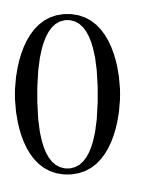

ne of America's greatest legacies is that it was built by people helping people. During the past several decades, this legacy has seen bumpy roads. However, within the past few years, Americans have been returning to traditional values and trying to bring the legacy of people helping people to a higher level.

Trees and flowers are an intricate part of our daily lives. Their presence improves the quality of our lives in many ways: environmentally, economically, socially, culturally, and physically through our health and wellbeing. Beautification in the community can have enormous benefits. How many times has someone asked you, "Isn't that a beautiful street, village, or town? The homes and yards are so beautiful." It makes sense for those associated with the green industry to commit themselves to aiding the beautification effort in some way, no matter how large or small.

This past year, Lake County Nursery (LCN) committed itself to shaping the future of our world through beautification. In September LCN, the Ohio Dept. of Natural Resources, the Cleveland Electric Illuminating Co., and CLEAN-LAND, OHIO cohosted a Beautification Stewards Conference at Lake Erie College. The conference's theme was "How to Increase Tax Revenues and Lessen Crime by the Proper Planting of Trees and Flowering Plants." A group of nationally known speakers made presentations to attendees from across the United States.

The following will retrace how we became a catalyst for people-plant interactions through beautification in our community in the past decade.

\section{Lake Erie College}

Even though LCN has been involved with various beautification projects in local communities for more than 25 years, it was a

President, Lake County Nursery, Inc., Ohio. project at Lake Erie College that awakened us to the powerful impact of beautification on our daily lives.

Lake Erie College, established in 1856, is a small liberal arts college in Painesville, Ohio, the county seat of Lake County. Its rich tradition and history, coupled with its location just west of the city square, has made it an integral part of the Painesville and Lake County communities for many years.

One day my wife commented on the terrible condition of the college grounds and how the once-beautiful campus had deteriorated. She asked if I could help restore the grounds.

Help was needed. Not only was Lake Erie College in trouble, but it also looked like it was in trouble. From 1982 to 1987, enrollment at the college had declined $42 \%$. There were many rumors that this landmark institution might close. I realized that the college would have difficulty attracting new students and made an appointment with Clodus Smith, Lake Erie College's president, to discuss my plans to restore the campus. Smith was enthusiastic about the beautification project, agreeing that it was becoming increasingly difficult to promote the college as a quality educational institution because of its decaying appearance.

The beautification project received almost immediate, widespread support. Many civic-minded community and business leaders became involved.

A landscape architect drew a master beautification plan; many area nurseries donated plants; a roofing company repaired or replaced several roofs; an asphalt company donated labor and materials for parking lots and sidewalks; a painting company repainted a fence enclosing much of the campus; a concrete firm donated new steps, replacing those at some building entrances that were closed; and an architectural firm designed and helped fund elegant, hand-carved entrance signs.

Since the beautification program began, enrollment at the college has increased $55 \%$.

\section{'Americans \\ have been... trying to bring \\ the legacy of people helping people to a higher level."}


and about 125 people attended. Next year, with increased publicity, an even greater turnout is expected.

This project already has motivated several other communities to follow Painesville's lead in beautification. The local Kiwanis Club has made beautification their group goal for 1992. City officials have budgeted funds for beautification in 1992 .

I believe this project was an attempt to re-establish America's rich heritage of hard work and people helping others. If this beautification project had been bid out to contractors, the cost would have been $\$ 70,000$ to $\$ 95,000$. Instead, it cost about $\$ 31,000$, including the plants, sod, timber, mulch, topsoil, and automatic underground irrigation system.

As our urban communities become more compressed, plants are going to continue to play an even greater part in the therapeutic world of family bonding. In rural areas with open spaces, you need not be so concerned with landscape design, but in a true urban setting, you must use the proper plants.

Those of us in the green industry too often undervalue and do not recognize the full potential of our products. Our products are more than just pretty things to observe. In addition to the environmental benefits that plants provide, many studies have shown that proper plantings reward us with many positive psychological feelings about our surroundings. In many areas where beautification projects have been successfully completed, significant decreases in crime have been shown, besides dramatic increases in property values.

\section{Guidelines}

For those interested in a project of this magnitude, leadership is not enough. You must observe certain key principles.

1) Be a facilitator of excellence. Recognize and know the deci- sion-makers of the community, whether it be city officials, civic and business leaders, or any people of influence.

2) Develop a comprehensive outline for all levels of participation.

3) Show benefits to all donors and make them aware of the harmony and sense of inner goodness they will create and receive.

4) Give facts about crime reduction, passive recreation, the therapeutics ofplants, population growth, environmental and economic benefits, energy conservation, and noise abatement.

5) Make only wise investments in plants should be the first ruleplant only high-quality, lowmaintenance plants. Suggest a qualified nursery operator for the beautification team.

6) Prepare news releases to promote awareness about the project. You may receive additional unexpected help.

7) Recognize the efforts of all people involved in the project to maintain community spirit. Whether it be award certificates, publishing names in the newspaper, or a party, show your gratitude for their help.

People-plant involvement can add tremendous value to a community. We encourage those in the green industry to become a catalyst by organizing these types of projects where they live and work. Do not wait to be asked, volunteer your services and become a leader by promoting the many benefits of beautification. While your reward may not be monetary, the sense of harmony and inner goodness you will bring to your community and yourself will last a lifetime and for future generations.

\author{
'People-plant \\ involvement can \\ add tremendous \\ value to a \\ community...the \\ sense of harmony \\ and inner \\ goodness you will \\ bring to your \\ community and \\ yourself will last \\ a lifetime and \\ for future \\ generations."
}

